\title{
Quantifying relations between surface runoff and aridity
}

\section{after wildfire}

René E. Van der Sant ${ }^{1,2 \star}$, Petter Nyman ${ }^{1}$, Philip J. Noske ${ }^{1}$, Christoph Langhans ${ }^{1}$, Patrick N.J. Lane ${ }^{1}$ and Gary J. Sheridan ${ }^{1}$

${ }^{1}$ The University of Melbourne, ${ }^{2}$ Melbourne Water Corporation

${ }^{*}$ Corresponding author:

René E. Van der Sant

Address:

School of Ecosystem and Forest Sciences

The University of Melbourne

Baldwin Spencer Building 113

Parkville, Victoria 3010

Tel:

0412386162

E-mail:

rene.vandersant@melbournewater.com.au

Running Title:

Relations between surface runoff and aridity after wildfire

This is the author manuscript accepted for publication and has undergone full peer review but has not been through the copyediting, typesetting, pagination and proofreading process, which may lead to differences between this version and the Version of Record. Please cite this article as doi: 10.1002/esp.4370

This article is protected by copyright. All rights reserved. 


\section{Abstract}

Post-wildfire runoff and erosion are major concerns in fire-prone landscapes around the world, but these hydro-geomorphic responses have been found to be highly variable and difficult to predict. Some variation has been observed to be associated with landscape aridity, which in turn can influence soil hydraulic properties. However, to date there has been no attempt to systematically evaluate the apparent relations between aridity and post-wildfire runoff. In this study, five sites in a wildfire burned area were instrumented with rainfall-runoff plots across an aridity index (AI) gradient. Surface runoff and effective rainfall were measured over 10 months to allow investigation of short- (peak runoff) and longer-term (runoff ratio) runoff characteristics, over the recovery period. The results show a systematic and strong relation between aridity and postwildfire runoff ratio. The average runoff ratio at the driest $\mathrm{Al}$ site $(33.6 \%)$ was two orders of magnitude higher than at the wettest Al site (0.3\%). Peak runoff also increased with $\mathrm{Al}$, with up to a thousand fold difference observed during one event between the driest and wettest sites. The relation between Al, peak 15-minute runoff $\left(Q_{15}\right)$ and peak 15-minute rainfall intensity $\left(I_{15}\right)$ (both in $\mathrm{mm} \mathrm{h}^{-}$ $\left.{ }^{1}\right)$ could be quantified by the equation: $Q_{15}=0.1086 I_{15} \times A I^{2.691}(0.6<\mathrm{Al}<1.8$, $\left.0<I_{15}<45\right)$ (adjusted $\left.r^{2}=0.84\right)$. The runoff ratios remained higher at drier Al sites (Al 1.24 and 1.80) throughout the monitoring period, suggesting higher Al also lengthens the window of disturbance after wildfire. The strong quantifiable link which this study has determined between Al and post-wildfire 
surface runoff could greatly improve our capacity to predict the magnitude and location of hydro-geomorphic processes such as flash floods and debris flows following wildfire, and may help explain aridity related patterns of soil properties in complex upland landscapes.

Keywords: Fire; surface runoff; landscape aridity; erosion; debris flow 


\section{Introduction}

Understanding and being able to predict post-wildfire runoff and erosion are major concerns in fire-prone environments around the world (Moody et al., 2013). The timing, severity, and spatial extent of post-wildfire runoff and erosion can influence local stream morphology and ecological habitats (Benda et al., 2003, Miller et al., 2003, Rhoades et al., 2011), sediment budgets (Benda and Dunne, 1997), and landscape evolution (Istanbulluoglu et al., 2004). Negative impacts of post-wildfire runoff and erosion on people can vary from untreatable drinking water (Emelko et al., 2011, Smith et al., 2011, White et al., 2006) to infrastructure destruction and loss of life (Cannon et al., 2008, Jordan and Covert, 2009, Moody et al., 2013, Nyman et al., 2011). Accordingly, researchers and natural resource managers require information to quantify this spatial variation in post-wildfire runoff and erosion processes to better understand the role of wildfire in a landscape and the potential for postwildfire hazards and risk (Moody et al., 2013, Nyman et al., 2013). However, these hydro-geomorphic responses of landscapes to fire have been found to be highly variable and difficult to predict.

Following wildfire, hydrological changes such as removal of vegetation protecting the soil surface, increased soil water repellency (DeBano, 2000, Doerr et al., 2000), pore blockage due to fine particle inwash (Larsen et al., 2009), decreased surface roughness (Lavee et al., 1995), or raindrop compaction (Shakesby and Doerr, 2006) can result in a reduced rainfall 
threshold for runoff generation. Damaging surface runoff and erosion can, therefore, occur in response to short duration $(5,15$, or 30 minute) and/or higher frequency $(1,2$, or 5 year return interval) rainfall events (Moody et al., 2013, Nyman et al., 2011). Surface runoff in response to high intensity, short duration rainfall events is particularly important for the generation of debris flows (Gabet and Sternberg, 2008) and flash floods (Cannon et al., 2008) following fire.

The conversion of rainfall to runoff at the point scale is directly controlled by the infiltration-related properties of the soil, which are a function of factors such as structure (porosity), aggregate stability, water repellency, and moisture content. Information on these fine-scale soil properties is frequently unavailable and/or prohibitively resource intensive to collect, particularly in remote catchments. Spatially mappable surrogates for these often unavailable soil properties are therefore extremely valuable for predicting the post-wildfire hydrological responses.

Conceptual models of soil development (Jenny, 1941) and limited observations (Langhans et al., 2016, Noske et al., 2016, Sheridan et al., 2016) indicate that some of the enormous variability in surface runoff generation and post-wildfire erosion is associated with landscape aridity, which is the long-term balance between rainfall and evaporation (Budyko, 1974, Nyman et al., 2014, Prescott, 1949, Priestley and Taylor, 1972). Over long time scales, aridity-induced variation in moisture availability would 
primarily be expected to affect soil development, structure, and stability through weathering rates (Atkinson, 2004), biological activity (Jastrow and Miller, 1991), and the input and redistribution of organic matter and minerals (Attiwill and Leeper, 1990). This variation would result in intrinsic differences between soil hydraulic properties due to variation in soil structure (e.g. porosity) and composition (e.g. particle size, organic matter content) (Jenny, 1941). For example, soil depth and structural development is generally greater in wet Eucalypt forests compared with dry Eucalypt forests in south-east (SE) Australia, even though these forests may be only a few kilometres apart (Rees, 1982). Under normal forested conditions aridity-driven variation in soil surface hydrology and runoff generation is likely negligible as vegetation stabilises soil and reduces erosion (Cerdà and Doerr, 2005). Removal of vegetation by wildfire exposes the soil, highlighting differences in soil infiltration capacity. While some studies have observed a homogenisation of soil properties (such as soil moisture retention and soil temperature) by fire (Ebel, 2012a, Ebel, 2012b), observations and anecdotal evidence suggest aridity-driven differences in soil infiltration properties in SE Australian forests is enhanced after burning (Sheridan et al., 2016).

Previous studies of post-wildfire responses have included some features of moisture availability or aridity, but they have not used landscape aridity as a specific index or variable to quantitatively explain the responses. For instance, hillslope aspect can be used to contrast local variation in net radiation and 
aridity. A comparison of runoff ratios on opposite aspects in the Mediterranean showed that they were significantly higher (in some case by an order of magnitude) on drier slopes (equatorial facing with higher net radiation) compared with wetter slopes (polar facing with lower net radiation) (Cerdà et al., 1995, Marques and Mora, 1992, Wittenberg et al., 2014, Wittenberg et al., 2007). Ebel (2013) and Ebel et al. (2015) observed variation in hydrologic state changes between north- and south-facing slopes in the Colorado front range, USA. Hyde et al. (2007) also observed association between basin aspect and post-wildfire gully rejuvenation in this region with the highest rejuvenation overall in west- and southwest-facing basins. In SE Australia, the incidence of post-wildfire debris flows was linked with forest types occurring in drier systems and equatorial facing aspects (Nyman et al., 2011), as well as substantial differences in runoff and erosion response between aspects (Noske et al., 2016).

To date there has been no attempt to systematically evaluate the apparent relation between aridity and post-wildfire runoff. This knowledge gap limits our capacity to use aridity as a landscape-scale predictive tool. The objective of this study was to directly measure and quantify this relation, with emphasis on both the short- (peak runoff) and long-term (runoff ratio) runoff characteristics, from hillslopes following high severity wildfire. 


\section{Methods}

Hillslope surface runoff plots were established in a wildfire-burnt area across an aridity gradient (holding other factors as constant as possible) to isolate the effect of aridity on post-wildfire runoff. Surface runoff and effective rainfall (rainfall minus interception) were measured over 10 months across five sites of differing aridity. This allowed an investigation of short- (peak runoff) and long-term (runoff ratio) runoff characteristics, along with changes in runoff over the recovery period.

\section{Aridity index}

The aridity index (AI) was calculated using equation 1:

$$
A I=\frac{E p}{P}
$$

where $E p$ is potential evaporation and $P$ is annual precipitation. Ep was determined using Priestley-Taylor's model (Priestley and Taylor, 1972). This model of Ep is widely used due to its robust ability to represent evapotranspiration and its simplicity of use (Ai and Yang, 2016, Flint and Childs, 1991). Ep was estimated using net radiation and temperature that were downscaled from regional long-term meteorological observations to produce values at $20 \mathrm{~m}$ resolution (corresponding to the DEM) (Nyman et al., 2014). This downscaling incorporates the effects of aspect, slope gradient, and elevation on Ep (Nyman et al., 2014). The influence of aspect on aridity is considered during the estimation of direct shortwave radiation. Rainfall was obtained from gridded data (BoM) where point based rainfall records have 
been interpolated using a widely used $3 d$ interpolation algorithm, which accounts for systematic changes in rainfall with elevation (Xu and Hutchinson, 2011). Thus, Al represents variations in aridity due to both the local topographic effects (aspect and slope) as well as larger-scale effects associated with elevation and orographic rainfall. The estimated Al using Priestley-Taylor as the Ep forcing is similar to indices proposed by Budyko (1974) and Prescott (1949), but is better able to incorporate changes in temperature and therefore variation in aridity due to elevation. Budyko's radiative index of dryness was also calculated for each of the sites, obtained from Nyman et al. (2014), to provide compatibility with other studies of this type (see Table 1).

\section{Study area}

This study was conducted within the burned area from the Aberfeldy wildfire which occurred in 2013 within the Thompson State Forest between Aberfeldy $\left(37.68^{\circ} \mathrm{S} 146.37^{\circ} \mathrm{E}\right)$ and Walhalla $\left(37.93^{\circ} \mathrm{S} 146.45^{\circ} \mathrm{E}\right)$, Victoria, Australia (Figure 1).

The study area was burnt by a wildfire which started just south of the Aberfeldy township on 17th January 2013. The fire burnt for approximately six weeks and reached a total size of 86,000 ha (DEPI, 2014), with over half the area $(44,869 \mathrm{ha})$ burning within the first 24 hours. The burn severity across the forest was highly variable with unburnt patches occurring adjacent to high severity areas; $46 \%$ was burned at high severity (crown burn/scorch), $46 \%$ at 
medium severity (partial crown scorch and/or understorey burnt) and $8 \%$ at low severity (understorey partly unburnt) or unburnt. The fire was brought under control following rainfall (38 $\mathrm{mm}$ recorded in Aberfeldy) on 28th February 2013.

Victoria has a warm temperate climate with generally warm, dry summers and cool, wet winters (Kottek et al., 2006). In autumn and winter (March-August), precipitation in the study area is influenced by systems which result in long duration, low intensity rainfall events (BoM, 2014). In summer (DecemberFebruary), rainfall is often characterised by infrequent, high intensity storms. Monthly rainfall in the study area varies from an average of $70 \mathrm{~mm}$ (February) to $112 \mathrm{~mm}$ (October) (BoM Erica station $\left.37.98^{\circ} \mathrm{S} 146.37^{\circ} \mathrm{E}\right)$. Rainfall during the experimental period was similar to the long term mean of the region (Figure 2). Snowfall below $1200 \mathrm{~m}$ is typically light and the ground does not freeze; two light falls were recorded during winter in the study area. Average summer and winter temperature ranges in nearby Erica are $12.4^{\circ} \mathrm{C} / 23.2^{\circ} \mathrm{C}$ and $4.2^{\circ} \mathrm{C} / 10.8^{\circ} \mathrm{C}$ respectively. Mean daily solar radiation exposure at Aberfeldy is $15.1 \mathrm{MJ} \mathrm{m}^{-2}\left(4.2 \mathrm{kWh} \mathrm{m}^{-2}\right)$, daily insolation varies from an average of $24.5 \mathrm{MJ} \mathrm{m}^{-2}\left(6.8 \mathrm{kWh} \mathrm{m}^{-2}\right)$ in January (summer) to $5.9 \mathrm{MJ} \mathrm{m}^{-2}\left(1.6 \mathrm{kWh} \mathrm{m}^{-2}\right)$ in June (winter) (BoM, 2014).

The value of the aridity index varies across the study area as a function of regional scale rainfall patterns, orographic rainfall gradients, and topographic control of solar radiation exposure. Large scale patterns in Al occur due to the 
rain shadow created by the Baw Baw Mountains to the west (Parks Victoria, 2012). At smaller scales, strong Al differences are observed between northand south-facing hillslopes, and between areas of high and low relief (Figure 1).

Vegetation of the study area is dominated by dry mixed species Eucalypt forest (including Mountain Grey Gum Eucalyptus cypellocarpa, Messmate E. obliqua, Manna Gum E. viminalis, Broad-leaf Peppermint E. dives, and Narrow-leaf Peppermint E. radiata), with an understorey of grasses, bracken fern (Pteridium esculentum), and small shrubs (DSE, 2004). In higher rainfall areas (>1000 mm per year), Mountain Ash (E. regnans) begins to dominate the overstorey, moving to a pure stand as annual rainfall increases, with an understorey of tree ferns (Dicksonia antarctica, Cyathea australis) (Costermans, 2009).

The geology of the area is predominantly Palaeozoic (Silurian to early Devonian) sedimentary and metamorphic marine deposits, with some granitic intrusions (Birch et al., 2003). It is part of the East Victorian Uplands (Dissected uplands), an area which was uplifted by slow, periodical, tectonic movements starting in the early Cretaceous (Cochrane et al., 1995). Deep, steep-sided valleys separated by narrow ridges dominate the area due to river downcutting following this uplift. Soils derived from this geology are typically brown earths (Dermosols) and shallow stony loams (Kandosols) (Isbell, 2002). 
Disturbances other than bushfire in the study area include tourism, timber harvesting, and mining. No timber harvesting is recorded at the research sites within the period of reliable harvesting records for this area, which extends from approximately 1950 to the present (Vic Forests, 2014, pers. comm., 9 July). Gold mining occurred in parts of the forest from the 1860s, particularly towards the township of Walhalla in the south (Lloyd and Combes, 2010). The sites were not located within an area likely to have been disturbed by registered mines and none of the typical evidence of past gold mining activity was apparent from visual inspection at each of the experimental sites (e.g. abandoned mining structures, collapsed mine-shafts, stone water races).

\section{Site selection and experimental set up}

Five sites $(20 \times 20 \mathrm{~m})$ were selected and instrumented within the Aberfeldy burned area to cover a wide range of aridity index (Al) values (Table 1 and Figure 3). Site Al was determined in the field using a real-time GPS-ArcGIS interface with the mapped index. Sites were chosen with the objective of keeping factors other than $\mathrm{Al}$ constant or within a narrow range, so that the $\mathrm{Al}$ level was the primary difference between the sites. Burn severity was patchy across the burned area and the mapped burn severity based on canopy assessment (satellite or aerial photography) was not always the best indicator of soil burn severity. For example, the lowest Al instrumented site (Al 0.65, see Table 1) was classified as a lower severity burn (class 4 understorey burn), but destruction of biomass indicated that the burn severity near the soil 
surface was comparable to the other sites. Burn severity on the ground was considered high where all surface fuels were burnt (material $<2 \mathrm{~mm}$ destroyed), understorey shrubs had been burnt or scorched, and the canopy had been scorched or flame heights were >15 m. Upper to middle hillslope positions, with a slope of $25-30$ degrees were chosen to reduce variation due to topographic position. Sites were located on a planar section of hillslope to avoid i) differences between slope curvature (concave vs convex), and ii) flow direction and channelling effects. All sites were located on sedimentary or metamorphic bedrock according to the Land System of Victoria GIS layer (LSYS250) as detailed in Rees (2000). Field observations suggest soils at Al 0.65 were slightly sandier, being influenced by the nearby igneous granitic intrusion which forms Mt Useful (Mt Useful Granodiorite). Installation of monitoring equipment at the sites was completed in June 2013, approximately 4 months after the fire, and the sites were active until April of the following year (14 months since fire). At each site, post-wildfire runoff and rainfall was monitored with:

- Two 8m long bounded plots with tipping buckets

- One throughfall trough setup with tipping bucket

- One data logger (Tain Electronics)

Basic site setup is shown in Figure 4. Components of the study were all located within a $20 \times 20 \mathrm{~m} \mathrm{Al}$ pixel and placed to avoid any interference with each other. 


\section{Measuring surface runoff and rainfall}

Bounded plots $(8 \times 1.5 \mathrm{~m})$ were constructed using galvanised steel sheet edging (105 x $15 \mathrm{~cm}, 1.5 \mathrm{~mm}$ thickness) (Figure 4). Each plot ended in a collector and pipe connected to a tipping bucket. Plot edging was hammered (using mallets) into the soil to a depth of $3-5 \mathrm{~cm}$, with an overlap at each end of approximately $5 \mathrm{~cm}$. For stability, the sheets were then riveted together and the joins sealed with silicone sealant. Concrete was used to seal the gap between the soil and the downslope edge of the plot and in front of the collector to ensure surface runoff would not undermine or leak through these areas. This method worked well and no undermining was detected during the study. Wire mesh was also placed across the plot above the collector to prevent stones and other large debris from blocking the collector, and drainage lines were dug around the outside of the plots to protect the plots from intrusion of runoff generated further upslope. The box collector was attached to a pipe (50 $\mathrm{mm}$ diameter) and flexible tubing which carried water to the tipping buckets. Tipping buckets had a capacity of $\sim 500 \mathrm{~mL}$ per tip. Each tipping bucket was affixed with screws on top of a concrete slab $(40 \times 40 \mathrm{~cm})$, the slabs were levelled on soil cuttings in the hillslope.

Effective rainfall (rainfall minus interception) was measured below the canopy at a height of approximately $30 \mathrm{~cm}$ using throughfall troughs. Throughfall troughs were constructed from two galvanised steel roofing gutters $(7.0 \mathrm{x}$ $0.15 \mathrm{~m}$ ) running parallel downslope and emptying into a tipping bucket. Two lengths were used to increase the catchment area and allow for the use of a 
$500 \mathrm{~mL}$ tipping bucket. Lengths were suspended just above the ground using wire and steel fence post; this setup allowed the troughs to be close to the ground but unaffected by microtopography, and allowed for flexibility when struck by falling debris (e.g. tree branches). A downpipe at the end of each gutter connected to a Y-shaped pipe, which allowed water to flow together from both lengths. This was then connected to the standard collection pipe and flexible hose leading to a tipping bucket (Figure 4).

The runoff and rainfall data were obtained using a manual counter and a reed switch attached to a data logger (Tain Electronics). Magnets on the sides of the tipping buckets activated both the counter and the reed switch when tipped. The data loggers recorded the number of tips in three minute intervals. The sites were visited at intervals of 15-20 days, over the 10-month monitoring period. At each visit data were recorded from the manual counters and downloaded from the loggers.

\section{Data handling}

Manual counter data were checked against logger data to identify problematic periods and they were adjusted before analysis by substituting logger data when there were known to be problems with a manual counter. Logger data quality were also checked by comparing daily rainfall/runoff patterns between sites. Periods of missing or potentially incorrect data were identified and removed from further analysis. At site Al 0.80 rainfall was not recorded by a data logger until 4 months after installation of the plots, in October 2013. 
However, as sites Al 0.75 and Al 0.80 were located approximately $500 \mathrm{~m}$ apart and had similar vegetation cover, missing rainfall data were estimated using an empirical regression of the existing data. This was checked against manual counter data obtained over the same period.

\section{Data analysis}

Logger data recording effective rainfall (beneath the canopy) were analysed to identify all rainfall events over $5 \mathrm{~mm}$, to link peak rainfall with peak runoff. Data were first summarised by day, then by hour, to identify individual rainfall events with a total of $5 \mathrm{~mm}$. Rainfall events were considered discrete when there was no tipping for a period of an hour, this ensured that long duration, low intensity rainfall events were also included.

To compare between rainfall events, the maximum rainfall intensity over a 15minute period $\left(I_{15} \mathrm{~mm} \mathrm{~h}^{-1}\right)$ was used. The average intensity over time is a commonly used metric, but it is important to choose a rainfall descriptor appropriate to the research (Dunkerley, 2010). Intervals between 10 to 30 minutes have been shown to correlate well with rainfall properties driving postwildfire runoff and erosional response (Moody et al., 2013).

The peak rainfall intensity $\left(I_{15} \mathrm{~mm} \mathrm{~h}^{-1}\right)$ was calculated using the flow rate from the throughfall troughs. The peak 15-minute runoff $\left(Q_{15} \mathrm{~mm} \mathrm{~h}^{-1}\right)$ was calculated in a similar manner by identifying the highest flow rate from the plots over a 15-minute period within each rainfall event. 
Runoff ratio $(R R)$ for the plots was calculated using the total runoff in $\mathrm{mm}(Q)$ of the plots and effective rainfall in $\mathrm{mm}\left(P_{n}\right)$ recorded from the throughfall troughs by the following equation:

$$
R R=\frac{Q}{P_{n}}
$$

\section{Results}

\section{Al and runoff response}

Variation in runoff response across the Al gradient could be observed over the entire monitoring period and during individual storm events. The runoff ratio (equation 2) was positively correlated to Al by a power law (equation 3).

$$
R R=0.06394 A I^{2.822} \quad(0.6<\mathrm{Al}<1.80)
$$

where $\mathrm{RR}$ is runoff ratio and $\mathrm{Al}$ is aridity index.

Equation 3 suggests Al can explain 91\% of variability in the data (adjusted $r^{2}$ $0.91)$, within the $\mathrm{Al}$ range tested $(0.6<\mathrm{Al}<1.8)$ (Figure $5 \mathrm{a})$. This fitted equation was also consistent with runoff ratio data in the first year after fire from Noske et al. (2016).

Runoff response during individual storm events, in the form of peak runoff $\left(\mathrm{mm} \mathrm{h}^{-1}\right)$, also showed a strong variation with Al. The change in $Q_{15}$ with increasing $I_{15}$ was more pronounced for higher Al sites compared with lower Al (Figure 5b). A fitted surface model, equation 4, explained $84 \%$ of variability in the data (adjusted $r^{2} 0.84$ ). 


$$
Q_{15}=0.1086 I_{15} \times A I^{2.691}\left(0.6<\mathrm{AI}<1.8,0<I_{15}<45\right)
$$

Event-based runoff ratio was similarly correlated with peak rainfall intensity across the aridity gradient, with a fitted surface model resulting in an exponent of $\mathrm{Al}^{2.695}$.

Runoff ratio and peak runoff can be highly dependent on rainfall event characteristics, especially intensity (Moody and Martin, 2001). An analysis of rainfall events over $5 \mathrm{~mm}$ (24-30 events per site) suggests there were no potentially confounding patterns in the intensity of rainfall events between sites or with time since fire. Given this and other variables affecting runoff response were held constant, observed variation in runoff response could be attributed to aridity (Table 2).

Aridity-driven variation in runoff response was most pronounced during the highest intensity rainfall event (21 March 2014) observed 13 months following fire. Site Al 0.65 experienced the highest rainfall intensity $I_{15} 45.6 \mathrm{~mm} \mathrm{~h}^{-1}$ and the lowest peak runoff $Q_{15} 0.0007 \mathrm{~mm} \mathrm{~h}^{-1}$. In contrast, site Al 1.80 produced the highest peak runoff during this event $Q_{15} 0.016 \mathrm{~mm} \mathrm{~h}^{-1}$ despite having the second lowest rainfall intensity $I_{15} 23.3 \mathrm{~mm} \mathrm{~h}^{-1}$.

\section{Temporal variation of runoff}

Aridity-driven variation in runoff remained evident throughout the study despite expected changes in seasonal weather and soil and vegetation recovery (time since fire). Cumulative runoff across the sites showed a strong positive 
relation with $\mathrm{Al}$ (Figure 6a), with the higher Al sites (e.g. Al $1.80=0.336$ $\mathrm{mm}_{\text {runoff }} / \mathrm{mm}_{\text {rain }}$ ) producing ca. 170 times more runoff (per unit rainfall) than the lower Al sites (e.g. Al $0.65=0.002$ mm runoff $/ \mathrm{mm}_{\text {rain }}$ ) (Figure 6a).

Runoff ratio across all sites reduced over time as the sites recovered, but the trend of higher runoff with higher Al continued for the entire period (Figure 6). The average runoff ratio for site 1.80 (33.6\%) was substantially higher than all other sites for the entire monitoring period. With similar rainfall conditions at all the sites and no systematic temporal changes in rainfall intensity over this period, this reduction in runoff generation can be attributed to "recovery" (of both soil and vegetation). Results suggest recovery (reduction in runoff generation) is almost complete at lower Al sites by the end of the monitoring period (14 months since fire), while higher Al sites still exhibit substantial runoff generation.

\section{Discussion}

\section{Aridity and runoff response}

The results show a systematic and extremely strong relation between aridity index $(\mathrm{Al})$ and post-wildfire runoff. The runoff ratio, averaged over the whole monitoring period, at the highest Al site (33.6\%) was two orders of magnitude greater than the lowest Al site (0.3\%). Peak runoff also increased with $\mathrm{Al}$, with up to a thousand-fold difference observed during the highest intensity rainfall event. This pattern was evident throughout the whole monitoring period, despite variations in seasonal rainfall and post-wildfire recovery. These results 
provide a strong empirical linkage between $\mathrm{Al}$ and post-wildfire runoff response and quantify these relations across a wide range of Al values. In previous work, these relations have only been opportunistically investigated across a relatively narrow range of $\mathrm{Al}$ values. For example, the interpretation of the data presented in Sheridan et al. (2016) was limited by different measurement techniques and other confounding variables such as scale and geology. The results from experimental work in the Stony Creek catchments reported by Noske et al. (2016) in north-east Victoria showed distinct differences with aridity, but the aridity range studied was very small and limited to only two levels (Al 1.77 (polar facing) and Al 1.60 (equatorial facing)). In their work on predicting debris flows in SE Australia, Nyman et al. (2015) found that Al was an important predictor of post-wildfire debris flow occurrence, but that its effect was only apparent in the statistical model when the range of $\mathrm{Al}$ was large (Al 0.31-2.59). The current study reinforces the value of the Al as a proxy for post-wildfire hydro-geomorphic processes and, for the first time, uses a controlled experiment to relate rainfall-runoff response to Al after high severity wildfire.

In a global context, a positive relation between aridity and post-wildfire runoff has also been observed and is considered to be linked to a climosequence of soil development. Climosequence studies testing the relation between soil properties and climatic factors often examine landscape scale gradients (Jenny, 1941), but in complex terrain climatic variation may be sufficiently 
large over small spatial scales to influence soil properties. The role of a climosequence at local scales is frequently explored by using aspect to generate an aridity gradient (Cerdà et al., 1995, Ebel et al., 2015, Marques and Mora, 1992, Wittenberg and Inbar, 2009, Wittenberg et al., 2014, Wittenberg et al., 2007). For example, Marques and Mora (1992) observed a difference in runoff ratio between aspects, average 5.8\% (equatorial facing) compared to $1.5 \%$ (polar facing), on burnt hillslopes in the north of Spain. In the north-west United States, aridity-driven effects have been documented across both local (Hyde et al., 2007) and regional (Wondzell and King, 2003) scales. However, it is important to note that the strength of a climosequence or aridity-driven variation in soil development processes will vary depending on the relative range and strength of other variables that influence soil development, such as geologic properties and age, catena position, and topography.

The results of this study seem to indicate that the climosequence (represented by $\mathrm{Al}$ ) is closely associated with runoff processes and, thus aridity is a primary control on soil hydraulic properties in this domain. Although no direct soil properties or vegetation recovery data are presented here, runoff patterns observed during the study are in line with general theory that soil structural development, soil infiltration capacity, and vegetation growth are lower under more arid conditions (Jenny, 1941, Thompson et al., 2010). For example, Nyman et al. (2010) and Nyman et al. (2014) found macropores (>0.5 mm) 
contributed substantially to soil infiltration and runoff generation in the post-fire hydrophobic environment, in SE Australia (up to $70 \%$ and $95 \%$ of the fieldsaturated and ponded hydraulic conductivity respectively). A more arid environment would be expected to have reduced biologic activity (Ossola and Nyman, 2017), organic matter input (Ebel, 2012a, Moody and Nyman, 2013), and soil development, and consequently reduced formation and stability of pores, especially large pores (Beven and Germann, 1982, Jastrow and Miller, 1991). Similarly, the level of biomass and recovery of vegetation following wildfire would be expected to be lower at higher aridity sites (Wittenberg et al., 2014). Vegetation cover and biomass has been correlated with infiltration capacity (Anderson and Burt, 1990, Dunne, 1978), particularly in water-limited systems such as those experienced in the forests of SE Australia (Thompson et al., 2010, Noske et al., 2016, Lane et al., 2012). The recovery of ground cover following wildfire has also been shown to be important in increasing soil infiltration, and decreasing runoff generation and erodibility (Cerdà and Doerr, 2005, Marques and Mora, 1992, Moody and Nyman, 2013). In line with these results, in the current study, aridity-driven variation in vegetation cover and recovery (Figure 3) corresponds with patterns of runoff ratio (Figure 6 a and b).

The variation between sites is particularly clear immediately following fire. Over time, the runoff ratio of each site decreases, as does the absolute difference between sites (Figure 6b), supporting the interpretation that fire 
enhances runoff potential (Sheridan et al., 2016). If runoff measurements at the end of the monitoring period are reflective of unburnt levels, this suggests the background variation in runoff generation between sites, particularly the lower aridity sites, is small. Following fire, runoff generation is substantially enhanced with all sites showing distinctly different runoff generation levels. Runoff levels stabilise approximately 8 months after fire, with the lower aridity sites recovering slightly faster than the higher aridity sites (Figure 6b), which is consistent with observed vegetation patterns (Figure 3). The runoff ratio recovery shown in Figure $6 \mathrm{~b}$ also suggests that resistance to the effects of wildfire is lower at high aridity sites compared with the low aridity sites, while resilience to wildfire is high across all aridities. Short-term effects of wildfire which have been shown to be important in runoff generation include soil water repellency (Doerr et al., 2000, Shakesby et al., 2000), vegetation cover (Wittenberg et al., 2007), and soil sealing (Larsen et al., 2009).

The most pronounced aridity-driven variation in runoff and erosion is greatest directly after the fire, and lessens over time as the sites recover. Therefore, accounting for the time after fire might improve the predictive relations determined in this study. The empirical equation determined from our observations (equation 3) already accounts for a large amount of variation (91\%), but if a more accurate prediction of post-wildfire runoff were required, including time since fire as a variable would likely be beneficial. This inclusion 
may be particularly useful amongst higher Al sites (above 1.24), where absolute change in runoff ratio is highest.

The observed relations between both $\mathrm{Al}$ and runoff ratio, and $\mathrm{Al}$ and peak runoff with peak rainfall intensity suggests the effect of $\mathrm{Al}$ is threshold dependent. Although only five Al levels were measured, the results show a dramatic increase in average runoff ratio between the lower Al sites (0.65 and 0.75) and the higher Al sites (1.24 and 1.80), suggesting a threshold point where Al becomes an important factor in predicting runoff response. Research into post-wildfire debris flow processes also suggests a threshold of runoff is required for initiation (Cannon et al., 2003). Results from this study suggest lower Al sites have a lower initial runoff ratio following fire, and recover to negligible levels of runoff faster than high Al sites. This means lower Al would more often remain below the debris flow runoff initiation threshold, even under high intensity rainfall.

\section{Implications for hydrologic and geomorphic processes}

At the landscape scale, aridity-driven variation in post-fire surface runoff could control landscape scale hydrologic and geomorphic processes, including flooding, runoff-initiated debris flows, and long-term erosion rates. Following high severity wildfire, the probability of flash flooding and runoff-initiated debris flow occurrence is considered to be strongly dependent on surface runoff potential and rainfall within the recovery window (Cannon et al., 2008, Jones et al., 2014, Prosser and Williams, 1998). Results of the study show higher Al 
is associated with the prolonged generation of substantial surface runoff and peak flows. This is coupled with slower post-wildfire recovery, which increases the probability of an erosive rainfall event occurring within the recovery window. For example, under a rainfall event with a one-year return interval for the area (approximately $I_{15}=38 \mathrm{~mm} \mathrm{~h}^{-1}$ ) results suggest the peak runoff from the highest Al site would be 20 times greater than the lowest $\left(0.0008 \mathrm{~mm} \mathrm{~h}^{-1}\right.$ at site Al 0.65 to $>0.017 \mathrm{~mm} \mathrm{~h}^{-1}$ at site Al 1.80 ). Thus, low aridity sites might only pose a major flooding or erosion risk under a 100-year rainfall event, while higher aridity sites might pose a risk under 1-5 year rainfall events. Post-wildfire debris flows in SE Australian forested catchments have been initiated under rainfall events with an $I_{30}$ of $35 \mathrm{~mm} \mathrm{~h}^{-1}$ (Nyman et al., 2011), a rainfall event which has an average return interval of 2-5 years for this area. Aridity-related variation in post-fire surface runoff may also contribute to the longer term evolution of the soil profile in fire-prone forested uplands. Under the same fire regime, lower aridity areas would be expected to have lower potential erosion than higher aridity areas, resulting in a divergence between their erosion rates. In forested environments in the United States, field studies and modelling suggest post-wildfire erosion and debris flow processes contribute a substantial portion of long-term erosion (Istanbulluoglu et al., 2004, Meyer et al., 2001, Pierce et al., 2004). In Australia, Smith et al. (2012) calculated a potential depletion of the soil profile of $0.2-1 \mathrm{~m}$ in $8,700-43,500$ years beneath dry Eucalypt forest due to post-wildfire debris flow processes. 
In addition, there is a potential for positive feedback whereby higher firerelated erosion rates result in shallower soils, a more open forest canopy, drier fuels, and as a result, more frequent fire and erosion.

Over the long term this spatial variation in aridity-driven erosion potential could lead to variation in landscape morphology. For example, hillslope asymmetry between polar and equatorial facing slopes has been attributed to differences in insolation and erosional processes (Burnett et al., 2008, Cerdà et al., 1995, Istanbulluoglu et al., 2008, Marques and Mora, 1992, Munro and Huang, 1997, Selkirk et al., 2001). Poulos et al. (2012) observed distinct patterns in hillslope asymmetry across mountainous landscapes in the United States, and concluded that specific dominant process controlled asymmetry development within a region. Given the high correlation between Al and postwildfire runoff potential in SE Australian forests observed in the results of this study, aridity could be a dominant control on hillslope evolution in this region.

\section{Implications for practical application and prediction}

With the strong and quantified associations identified in this paper, postwildfire hillslope surface runoff can now be spatially mapped using Al as a proxy, within the $\mathrm{Al}$ range tested $(0.6<\mathrm{Al}<1.8)$. This is the first study to directly investigate these relations in a burnt environment, and the strong relations identified suggest Al provides a means to estimate processes and/or properties which are resource intensive or impractical to determine through field work. Although limited in scope (e.g. burn severity, slope, geology), the 
findings of the study could be used to convert an Al layer into one layer showing probable hydrological attributes of the soil surface after fire, including runoff generation potential and potential peak runoff. These characteristics could also be linked to post-wildfire flash flooding and debris flow occurrence probability. Aridity index (and associated relations) could therefore be incorporated into existing models, planning and assessment of soil and water resources, post-wildfire risk assessments, and further research and monitoring tools.

\section{Conclusions}

The results show a systematic and strong relation between $\mathrm{Al}$ and postwildfire runoff. These findings have important implications for spatial variation of post-wildfire runoff event sizes and timing, with higher Al resulting in greater probability of substantial erosion impacts, floods, and debris flows following fire. The strong quantifiable link which this study has made between Al and post-wildfire surface runoff greatly improves our capacity to predict and map post-wildfire processes. Although this study has shown empirically that the variation in post-wildfire surface runoff is strongly related to an aridity gradient, the soil hydraulic processes underlying this variation are unknown. Future research should focus on identifying underlying causes and exploring the implications of aridity-driven variation in post-fire soil hydraulic properties to improve and expand our predictive capacity. 


\section{Acknowledgement}

This work was made possible through funding from the Bushfire Cooperative Research Centre, Australia, and the Victorian Department of Environment, Land Water and Planning Integrated Forest Ecosystem Research program. The authors wish to thank the DEPI and VicForest staff in Erica, and our colleagues Daniel Metzen, Chris Sherwin, Assaf Inbar, and Leila Kasmaei for their support. The authors would also like to thank the reviewers whose feedback and comments helped improve the manuscript.

\section{References}

Ai Z, Yang Y. 2016. Modification and Validation of Priestley-Taylor Model for Estimating Cotton Evapotranspiration under Plastic Mulch Condition. Journal of Hydrometeorology 17: 1281-1293. DOI: 10.1175/jhm-d-15-0151.1 Anderson MG, Burt TP. 1990. Process studies in hillslope hydrology. Chichester, West Sussex, England ; New York : Wiley, c1990.

Atkinson D. 2004. Weathering Slopes and Landforms. Hodder \& Stoughton: London

Attiwill PM, Leeper GW. 1990. Forest soils and nutrient cycles. Carlton, Vic. : Melbourne University Press, 1990.

Benda L, Dunne T. 1997. Stochastic forcing of sediment routing and storage in channel networks. Water Resources Research 33: 2865-2880. DOI:

10.1029/97wr02387 
Benda L, Miller D, Bigelow P, Andras K. 2003. Effects of post-wildfire erosion on channel environments, Boise River, Idaho. Forest Ecology and Management 178: 105-119

Beven K, Germann P. 1982. Macropores and water-flow in soils. Water Resources Research 18: 1311-1325. DOI: 10.1029/WR018i005p01311 Birch WD, Ferguson JA, Slots M. 2003. Geology of Victoria. Geological Society of Australia, Victoria Division: Melbourne

Budyko MI. 1974. Climate and life. Academic Press: New York Bureau of Meteorology (BoM). 2014. www.bom.gov.au. Commonwealth of Australia, Bureau of Meteorology. Web site accessed August 2014.

Burnett BN, Meyer GA, McFadden LD. 2008. Aspect-related microclimatic influences on slope forms and processes, northeastern Arizona. Journal of Geophysical Research-Earth Surface 113: F03002. DOI:

$10.1029 / 2007 j f 000789$

Cannon SH, Gartner JE, Parrett C, Parise M. 2003. Wildfire-related debrisflow generation through episodic progressive sediment-bulking processes, western USA. In Debris-Flow Hazards Mitigation: Mechanics, Prediction, and Assessment, Vols 1 and 2, Rickenmann D, Chen C (eds); 71-82.

Cannon SH, Gartner JE, Wilson RC, Bowers JC, Laber JL. 2008. Storm rainfall conditions for floods and debris flows from recently burned areas in southwestern Colorado and southern California. Geomorphology 96: 250-269. DOI: 10.1016/j.geomorph.2007.03.019 
Cerdà A, Imeson AC, Calvo A. 1995. Fire and aspect induced differences on the erodibility and hydrology of soils at La-Costera, Valencia, southeast Spain. Catena 24: 289-304. DOI: 10.1016/0341-8162(95)00031-2

Cerdà A, Doerr SH. 2005. Influence of vegetation recovery on soil hydrology and erodibility following fire: an 11-year investigation. International Journal of Wildland Fire 14: 423-437. DOI: 10.1071/wf05044

Cochrane GW, Spencer-Jones D, Quick GW. 1995. Introducing Victorian geology. Geological Society of Australia (Victorian Division): Melbourne, Vic Costermans LF. 2009. Native trees and shrubs of south-eastern Australia. Reed New Holland: Chatswood, N.S.W.

DeBano LF. 2000. The role of fire and soil heating on water repellency in wildland environments: a review. Journal of Hydrology 231: 195-206. DOI: $10.1016 / \mathrm{s} 0022-1694(00) 00194-3$

Department of Environment and Primary Industries (DEPI). 2014. http://www.depi.vic.gov.au/fireand-emergencies/managing-risk-and-learningabout-managing-fire/bushfire-history. Web site accessed August 2014. Department of Sustainability and Environment (DSE). 2004. Ecological Vegetation Class Benchmarks of the Highlands- Southern Fall Bioregion. The Victorian Government: Department of Sustainability and Environment, April 2004. 
Doerr SH, Shakesby RA, Walsh RPD. 2000. Soil water repellency: its causes, characteristics and hydro-geomorphological significance. Earth-Science Reviews 51: 33-65. DOI: 10.1016/s0012-8252(00)00011-8

Dunkerley DL. 2010. How do the rain rates of sub-event intervals such as the maximum 5-and 15-min rates (I-5 or I-30) relate to the properties of the enclosing rainfall event? Hydrological Processes 24: 2425-2439. DOI: 10.1002/hyp.7650

Dunne T. 1978. Field Studies of Hillslope Flow Processes. In Hillslope Hydrology, Kirkby MJ (ed). John Wiley \& Sons Ltd: Norwich: Great Britain; 227-294.

Ebel BA. 2012a. Impacts of Wildfire and Slope Aspect on Soil Temperature in a Mountainous Environment. Vadose Zone Journal 11. DOI:

10.2136/vzj2012.0017

Ebel BA. 2012b. Wildfire impacts on soil-water retention in the Colorado Front Range, United States. Water Resources Research 48: 1-12. DOI:

$10.1029 / 2012 w r 012362$

Ebel BA. 2013. Wildfire and Aspect Effects on Hydrologic States after the 2010 Fourmile Canyon Fire. Vadose Zone Journal 12. DOI:

$10.2136 / v z j 2012.0089$

Ebel BA, Rengers FK, Tucker GE. 2015. Aspect-dependent soil saturation and insight into debris-flow initiation during extreme rainfall in the Colorado Front Range. Geology 43: 659-662. DOI: 10.1130/g36741.1 
Emelko MB, Silins U, Bladon KD, Stone M. 2011. Implications of land disturbance on drinking water treatability in a changing climate: Demonstrating the need for "source water supply and protection" strategies. Water Research 45: $461-472$

Flint AL, Childs SW. 1991. Use of the Priestley-Taylor evaporation equation for soil water limited conditions in a small forest clearcut. Agricultural and Forest Meteorology 56: 247-260. DOI: http://dx.doi.org/10.1016/01681923(91)90094-7

Gabet EJ, Sternberg P. 2008. The effects of vegetative ash on infiltration capacity, sediment transport, and the generation of progressively bulked debris flows. Geomorphology 101: 666-673. DOI:

10.1016/j.geomorph.2008.03.005

Hyde KD, Woods SW, Donahue J. 2007. Predicting gully rejuvenation after wildfire using remotely sensed burn severity data. Geomorphology 86: 496511. DOI: 10.1016/j.geomorph.2006.10.012

Isbell RF. 2002. The Australian soil classification. CSIRO Australia: Collingwood, VIC Istanbulluoglu E, Tarboton DG, Pack RT, Luce CH. 2004. Modeling of the interactions between forest vegetation, disturbances, and sediment yields. Journal of Geophysical Research-Earth Surface 109. DOI: F01009 10.1029/2003jf000041 
Istanbulluoglu E, Yetemen O, Vivoni ER, Gutierrez-Jurado HA, Bras RL. 2008. Eco-geomorphic implications of hillslope aspect: Inferences from analysis of landscape morphology in central New Mexico. Geophysical Research Letters 35. DOI: L14403 10.1029/2008gl034477

Jastrow JD, Miller RM. 1991. Methods for assessing the effects of biota on soil structure. Agriculture Ecosystems \& Environment 34: 279-303. DOI: 10.1016/0167-8809(91)90115-e Jenny H. 1941. Factors of soil formation : a system of quantitative pedology. McGraw-Hill: New York Jones OD, Nyman P, Sheridan GJ. 2014. Modelling the effects of fire and rainfall regimes on extreme erosion events in forested landscapes. Stochastic Environmental Research and Risk Assessment 28: 2015-2025. DOI:

$10.1007 / \mathrm{s} 00477-014-0891-6$

Jordan P, Covert SA. 2009. Debris flows and floods following the 2003 wildfires in Southern British Columbia. Environmental and Engineering Geoscience 15: 217-234

Kottek M, Grieser J, Beck C, Rudolf B, Rubel F. 2006. World map of the Köppen-Geiger climate classification updated. Meteorologische Zeitschrift 15: 259-263. DOI: $10.1127 / 0941-2948 / 2006 / 0130$ Lane PNJ, Sheridan GJ, Noske PJ, Sherwin CB, Costenaro JL, Nyman P, Smith HG. 2012. Fire effects on forest hydrology: lessons from a multi-scale catchment experiment in SE Australia. In Revisiting Experimental Catchment 
Studies in Forest Hydrology, Webb AA, Bonell M, Bren L, Lane PNJ, McGuire

D, Neary DG, Nettles J, Scott DF, Stednick JD, Wang YH (eds); 137-143.

Langhans C, Lane PNJ, Nyman P, Noske PJ, Cawson JG, Oono A, Sheridan

GJ. 2016. Scale-dependency of effective hydraulic conductivity on fireaffected hillslopes. Water Resources Research 52: 5041-5055. DOI:

10.1002/2016wr018998

Larsen IJ, MacDonald LH, Brown E, Rough D, Welsh MJ, Pietraszek JH, Libohova Z, de Dios Benavides-Solorio J, Schaffrath K. 2009. Causes of PostFire Runoff and Erosion: Water Repellency, Cover, or Soil Sealing? Soil Science Society of America Journal 73: 1393-1407. DOI:

10.2136/sssaj2007.0432

Lavee H, Kutiel P, Segev M, Benyamini Y. 1995. Effect of Surface-Roughness on Runoff and Erosion in a Mediterranean Ecosystem - The Role of Fire.

Geomorphology 11: 227-234. DOI: 10.1016/0169-555x(94)00059-z

Lloyd BE, Combes H. 2010. Gold in the Walhalla region : West Gippsland, Victoria. Histec Publications: Hampton East, Vic.

Marques MA, Mora E. 1992. The influence of aspect on runoff and soil loss in a Mediterranean burnt forest (Spain). Catena 19: 333-344. DOI:

10.1016/0341-8162(92)90007-x

Meyer GA, Pierce JL, Wood SH, Jull AJT. 2001. Fire, storms, and erosional events in the Idaho batholith. Hydrological Processes 15: 3025-3038

This article is protected by copyright. All rights reserved. 
Miller D, Luce C, Benda L. 2003. Time, space, and episodicity of physical disturbance in streams. Forest Ecology and Management 178: 121-140 Moody JA, Martin DA. 2001. Post-fire, rainfall intensity-peak discharge relations for three mountainous watersheds in the western USA. Hydrological Processes 15: 2981-2993. DOI: 10.1002/hyp.386

Moody JA, Nyman P. 2013. Variations in soil detachment rates after wildfire as a function of soil depth, flow properties and root properties. U.S. Geological Survey Scientific Investigations Report 2012-5233

Moody JA, Shakesby RA, Robichaud PR, Cannon SH, Martin DA. 2013. Current research issues related to post-wildfire runoff and erosion processes. Earth-Science Reviews 122: 10-37. DOI: 10.1016/j.earscirev.2013.03.004 Munro DS, Huang LJ. 1997. Rainfall, evaporation and runoff responses to hillslope aspect in the Shenchong Basin. Catena 29: 131-144 Noske PJ, Nyman P, Lane PNJ, Sheridan GJ. 2016. Effects of aridity in controlling the magnitude of runoff and erosion after wildfire. Water Resources Research 52: 4338-4357. DOI: 10.1002/2015WR017611 Nyman P, Sheridan GJ, Lane PNJ. 2010. Synergistic effects of water repellency and macropore flow on the hydrolic conductivity of a burned forest soil, south-east Australia. Hydrological Processes 24: 2871-2887 Nyman P, Sheridan GJ, Lane PNJ. 2013. Hydro-geomorphic response models for burned areas and their applications in land management. Progress in Physical Geography 37: 787-812. DOI: 10.1177/0309133313508802 
Nyman P, Sheridan GJ, Smith HG, Lane PNJ. 2011. Evidence of debris flow occurrence after wildfire in upland catchments of south-east Australia. Geomorphology 125: 383-401. DOI: 10.1016/j.geomorph.2010.10.016 Nyman P, Sheridan GJ, Smith HG, Lane PNJ. 2014. Modeling the effects of surface storage, macropore flow and water repellency on infiltration after wildfire. Journal of Hydrology 513: 301-313. DOI:

10.1016/j.jhydrol.2014.02.044

Nyman P, Sherwin CB, Langhans C, Lane PNJ, Sheridan GJ. 2014.

Downscaling regional climate data to calculate the radiative index of dryness in complex terrain. Australian Meteorological and Oceanographic Journal 64: $109-122$

Nyman P, Smith HG, Sherwin CB, Langhans C, Lane PNJ, Sheridan GJ. 2015. Predicting sediment delivery from debris flows after wildfire. Geomorphology 250: 173-186. DOI: 10.1016/j.geomorph.2015.08.023 Oates A, Taranto M. 2001. Vegetation mapping of the Port Phillip and Westernport region. Environment DoNRa (ed). Arthur Rylah Institute for Environmental Research.

Ossola A, Nyman P. 2017. Aridity indices predict organic matter decomposition and comminution processes at landscape scale. Ecological Indicators: 531. DOI: 10.1016/j.ecolind.2017.03.049 Parks Victoria. 2012. Baw Baw National Park: Visitor Guide \& Mount St Gwinear Winter Guide. Parks Victoria. 
Pierce JL, Meyer GA, Timothy Jull AJ. 2004. Fire-induced erosion and millennial-scale climate change in northern ponderosa pine forests. Nature 432: $87-90$

Poulos MJ, Pierce JL, Flores AN, Benner SG. 2012. Hillslope asymmetry maps reveal widespread, multi-scale organization. Geophysical Research Letters 39. DOI: 10.1029/2012gl051283

Prescott JA. 1949. A Climatic Index for the Leachinf Factor in Soil Formation. Journal of Soil Science 1: 9-19

Priestley CHB, Taylor RJ. 1972. On the Assessment of Surface Heat Flux and Evaporation Using Large-Scale Parameters. Monthly Weather Review 100: 81-92. DOI: 10.1175/1520-0493(1972)100<0081:otaosh>2.3.co;2 Prosser IP, Williams L. 1998. The effect of wildfire on runoff and erosion in native Eucalyptus forest. Hydrological Processes 12: 251-265. DOI: 10.1002/(sici)1099-1085(199802)12:2<251::aid-hyp574>3.0.co;2-4 Rees D. 1982. A study of soils in the Reefton Experimental area; with particular reference to Hydrological properties. Authority SC (ed). Victorian Resouces Online http://www.nre.vic.gov.au/dpi/vro/portregn.nsf/pages/port_soil_surveys_reefto n.

Rees D. 2000. Land Systems of Victoria - Edition 3. Centre for Land Protection Research, Department of Natural Resources and Environment, Vic Technical Report no.56 
Rhoades CC, Entwistle D, Butler D. 2011. The influence of wildfire extent and severity on streamwater chemistry, sediment and temperature following the Hayman Fire, Colorado. International Journal of Wildland Fire 20: 430-442 Selkirk PM, Adamson DA, Downing AJ. 2001. Landform and vegetation change in the Greaves Creek Basin: An asymmetric hanging valley in the Blue Mountains, New South Wales. Australian Geographer 32: 45-75 Shakesby RA, Doerr SH, Walsh RPD. 2000. The erosional impact of soil hydrophobicity: current problems and future research directions. Journal of Hydrology 231: 178-191. DOI: 10.1016/s0022-1694(00)00193-1 Shakesby RA, Doerr SH. 2006. Wildfire as a hydrological and geomorphological agent. Earth-Science Reviews 74: 269-307 Sheridan GJ, Nyman P, Langhans C, Cawson J, Noske PJ, Oono A, Van Der Sant R, Lane PNJ. 2016. Is aridity a high-order control on the hydrogeomorphic response of burned landscapes? International Journal of Wildland Fire 25: 262-267. DOI: 10.1071/WF14079

Smith HG, Sheridan GJ, Lane PNJ, Noske PJ, Heijnis H. 2011. Changes to sediment sources following wildfire in a forested upland catchment, southeastern Australia. Hydrological Processes 25: 2878-2889. DOI: 10.1002/hyp.8050 Smith HG, Sheridan GJ, Nyman P, Child DP, Lane PNJ, Hotchkis MAC, Jacobsen GE. 2012. Quantifying sources of fine sediment supplied to post-fire 
debris flows using fallout radionuclide tracers. Geomorphology 139: 403-415. DOI: 10.1016/j.geomorph.2011.11.005

Thompson SE, Harman CJ, Heine P, Katul GG. 2010. Vegetation-infiltration relationships across climatic and soil type gradients. Journal of Geophysical Research-Biogeosciences 115. DOI: 10.1029/2009jg001134

White I, Wade A, Worthy M, Mueller N, Daniell T, Wasson R. 2006. The vulnerability of water supply catchments to bushfires: impacts of the January 2003 wildfires on the Australian Capital Territory. Australian Journal of Water Resources 10: 179-194

Wittenberg L, Inbar M. 2009. The Role of Fire Disturbance on Runoff and Erosion Processes - a Long-Term Approach, Mt. Carmel Case Study, Israel. Geographical Research 47: 46-56. DOI: 10.1111/j.1745-5871.2008.00554.x Wittenberg L, Malkinson D, Barzilai R. 2014. The differential response of surface runoff and sediment loss to wildfire events. Catena 121: 241-247. DOI: 10.1016/j.catena.2014.05.014

Wittenberg L, Malkinson D, Beeri O, Halutzy A, Tesler N. 2007. Spatial and temporal patterns of vegetation recovery following sequences of forest fires in a Mediterranean landscape, Mt. Carmel Israel. Catena 71: 76-83. DOI: 10.1016/j.catena.2006.10.007 Wondzell SM, King JG. 2003. Postfire erosional processes in the Pacific Northwest and Rocky Mountain regions. Forest Ecology and Management 178: 75-87. DOI: 10.1016/s0378-1127(03)00054-9 
Xu T, Hutchinson M. 2011. ANUCLIM Version 6.1 User Guide. The Australian National University, Fenner School of Environment and Society, Canberra. 


\section{Tables}

Table 1: Summary of specific characteristics of instrumented sites in the Aberfeldy fire (2013).

\begin{tabular}{|c|c|c|c|c|c|c|}
\hline $\begin{array}{c}\text { Site } \\
\text { aridity } \\
\text { index }^{a}\end{array}$ & Location $^{b}$ & Elevation $^{\mathbf{b}}$ & $\begin{array}{c}\text { Burn } \\
\text { severityc }\end{array}$ & $\begin{array}{l}\text { EVC } \\
\text { Group }^{d}\end{array}$ & Geology & Soil type ${ }^{\mathrm{e}}$ \\
\hline $\begin{array}{l}0.65 \mathrm{PT} \\
0.95 \mathrm{BD}\end{array}$ & $\begin{array}{c}37.71^{\circ} \mathrm{S} \\
146.52^{\circ} \mathrm{E}\end{array}$ & $1165 \mathrm{~m}$ & $\begin{array}{c}\text { Understorey } \\
\text { burnt (Class } \\
4 \text { ) }\end{array}$ & Damp forest & $\begin{array}{l}\text { Marine: sandstone, } \\
\text { thick to thin bedded, } \\
\text { siltstone, shale. } \\
\text { Border of Granitic } \\
\text { intrusion }^{f}\end{array}$ & $\begin{array}{c}\text { Brown } \\
\text { earths } \\
\text { Dermosol }\end{array}$ \\
\hline $\begin{array}{l}0.75 \mathrm{PT} \\
1.04 \mathrm{BD}\end{array}$ & $\begin{array}{c}37.83^{\circ} \mathrm{S} \\
146.50^{\circ} \mathrm{E}\end{array}$ & $701 \mathrm{~m}$ & $\begin{array}{l}\text { Tree canopy } \\
\text { and } \\
\text { understorey } \\
\text { burnt (Class } \\
\text { 1) }\end{array}$ & Damp forest & $\begin{array}{l}\text { Marine: sandstone, } \\
\text { thick to thin bedded, } \\
\text { siltstone, minor } \\
\text { conglomerate, } \\
\text { limestone lenses }\end{array}$ & $\begin{array}{c}\text { Brown } \\
\text { earths } \\
\text { Dermosol }\end{array}$ \\
\hline $\begin{array}{l}0.80 \mathrm{PT} \\
1.10 \mathrm{BD}\end{array}$ & $\begin{array}{c}37.83^{\circ} \mathrm{S} \\
146.50^{\circ} \mathrm{E}\end{array}$ & $753 \mathrm{~m}$ & $\begin{array}{l}\text { Tree canopy } \\
\text { and } \\
\text { understorey } \\
\text { burnt (Class } \\
\text { 1) }\end{array}$ & $\begin{array}{l}\text { Border of } \\
\text { Heathy dry } \\
\text { forest and } \\
\text { Damp forest }\end{array}$ & $\begin{array}{l}\text { Marine: sandstone, } \\
\text { thick to thin bedded, } \\
\text { siltstone, minor } \\
\text { conglomerate, } \\
\text { limestone lenses }\end{array}$ & $\begin{array}{c}\text { Brown } \\
\text { earths } \\
\text { Dermosol }\end{array}$ \\
\hline $\begin{array}{l}1.24 \mathrm{PT} \\
1.71 \mathrm{BD}\end{array}$ & $\begin{array}{c}37.85^{\circ} \mathrm{S} \\
146.47^{\circ} \mathrm{E}\end{array}$ & $742 \mathrm{~m}$ & $\begin{array}{l}\text { Tree canopy } \\
\text { and } \\
\text { understorey } \\
\text { burnt (Class } \\
\text { 1) }\end{array}$ & $\begin{array}{l}\text { Heathy dry } \\
\text { forest }\end{array}$ & $\begin{array}{c}\text { Marine: } \\
\text { undifferentiated: } \\
\text { sandstone, mudstone, } \\
\text { minor conglomerate }\end{array}$ & $\begin{array}{c}\text { Brown } \\
\text { earths } \\
\text { Dermosol }\end{array}$ \\
\hline $\begin{array}{l}1.80 \mathrm{PT} \\
2.41 \mathrm{BD}\end{array}$ & $\begin{array}{c}37.76^{\circ} \mathrm{S} \\
146.42^{\circ} \mathrm{E}\end{array}$ & $832 \mathrm{~m}$ & $\begin{array}{l}\text { Tree canopy } \\
\text { and } \\
\text { understorey } \\
\text { burnt (Class } \\
\text { 1) }\end{array}$ & $\begin{array}{l}\text { Heathy dry } \\
\text { forest }\end{array}$ & $\begin{array}{l}\text { Marine: sandstone, } \\
\text { thick to thin bedded, } \\
\text { siltstone, minor } \\
\text { conglomerate, } \\
\text { limestone lenses }\end{array}$ & $\begin{array}{l}\text { Shallow } \\
\text { stony } \\
\text { loams } \\
\text { Kandosol }\end{array}$ \\
\hline \multicolumn{7}{|c|}{$\begin{array}{l}{ }^{a} \text { Determined using the Priestley Taylor model (PT) and Budyko model (BD) }{ }^{b} \text { Recorded in the field using Garmin } \\
\text { GPS unit; }{ }^{c} \text { Fire severity layer for the Aberfeldy-Donnelly Creek fire developed by Department of Environment and } \\
\text { Primary Industries (DEPI); }{ }^{d} \text { Vegetation in Victoria is classified using Ecological Vegetation Classes (EVCs) which } \\
\text { represent commonly found species communities and often reflect moisture, soil, and elevation gradients, as well as } \\
\text { fire regime (Oates and Taranto, 2001) (DSE, 2004); }{ }^{\mathrm{e}} \text { Land System of Victoria GIS layer (LSYS250) as detailed in } \\
\text { Rees (2000) using the Factual Key of Northcote (1975); }{ }^{f} \text { Based on field observations. }\end{array}$} \\
\hline
\end{tabular}


Table 2: Summary of $>5 \mathrm{~mm}$ rainfall event characteristics at each instrumented site in the Aberfeldy fire (2013).

\begin{tabular}{|c|c|c|c|c|}
\hline Aridity Index & $\begin{array}{c}\text { Number of } \\
\text { events }\end{array}$ & $\begin{array}{c}\text { Median peak } I_{15} \\
\left(\mathrm{~mm} \mathrm{~h}^{-1}\right)\end{array}$ & $\begin{array}{c}\text { Minimum peak } I_{15} \\
\left(\mathrm{~mm} \mathrm{~h}^{-1}\right)\end{array}$ & $\begin{array}{c}{ }^{*} \text { Maximum peak } I_{15} \\
\left(\mathrm{~mm} \mathrm{~h}^{-1}\right)\end{array}$ \\
\hline 0.65 & 30 & 7.22 & 1.11 & 45.56 \\
\hline 0.75 & 28 & 6.67 & 2.22 & 34.44 \\
\hline 0.80 & 24 & 5.86 & 2.14 & 31.11 \\
\hline 1.24 & 27 & 6.67 & 2.22 & 16.67 \\
\hline 1.80 & 27 & 5.56 & 2.22 & 23.33 \\
\hline
\end{tabular}

* The maximum $I_{15}$ was recorded during one storm event (21 March 2014), the trend of these across the Al gradient is most likely related to the path followed by the storm compared to the location of sites. 


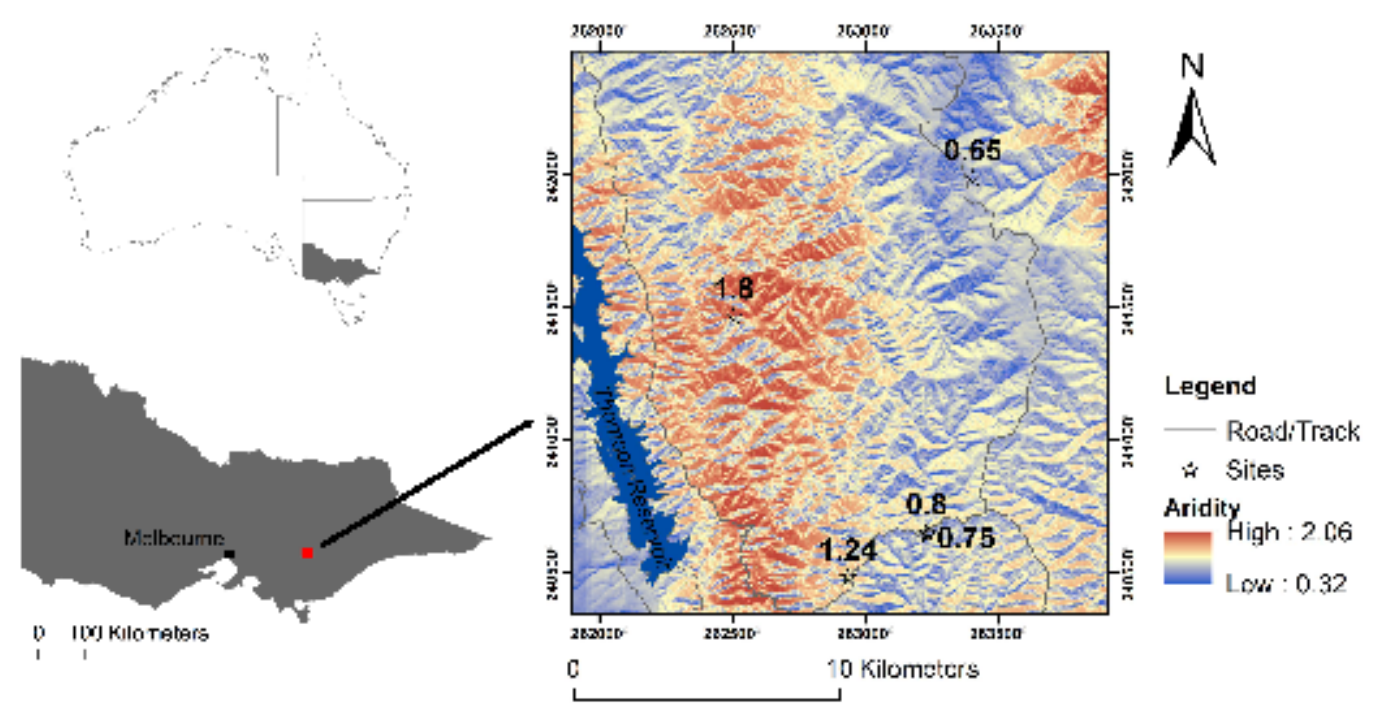

Figure 1

This article is protected by copyright. All rights reserved. 


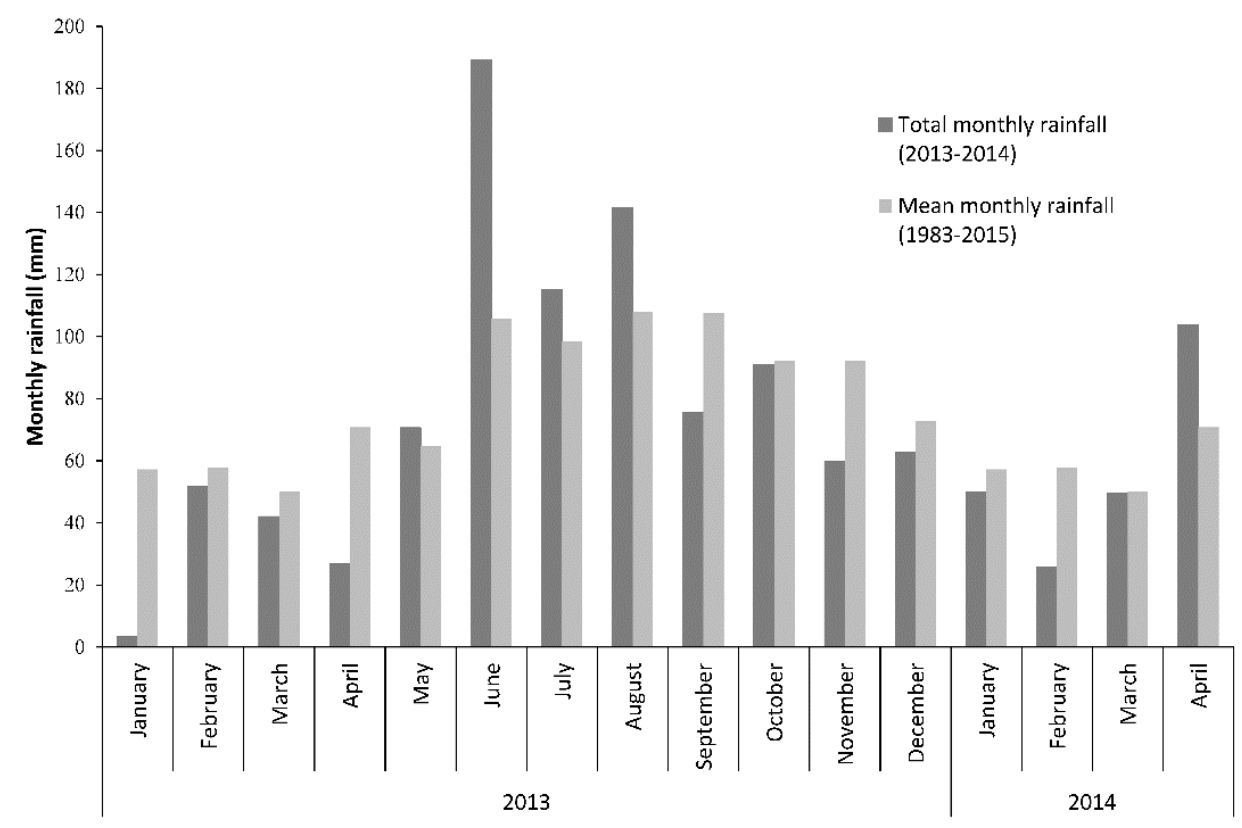

Figure 2

This article is protected by copyright. All rights reserved. 


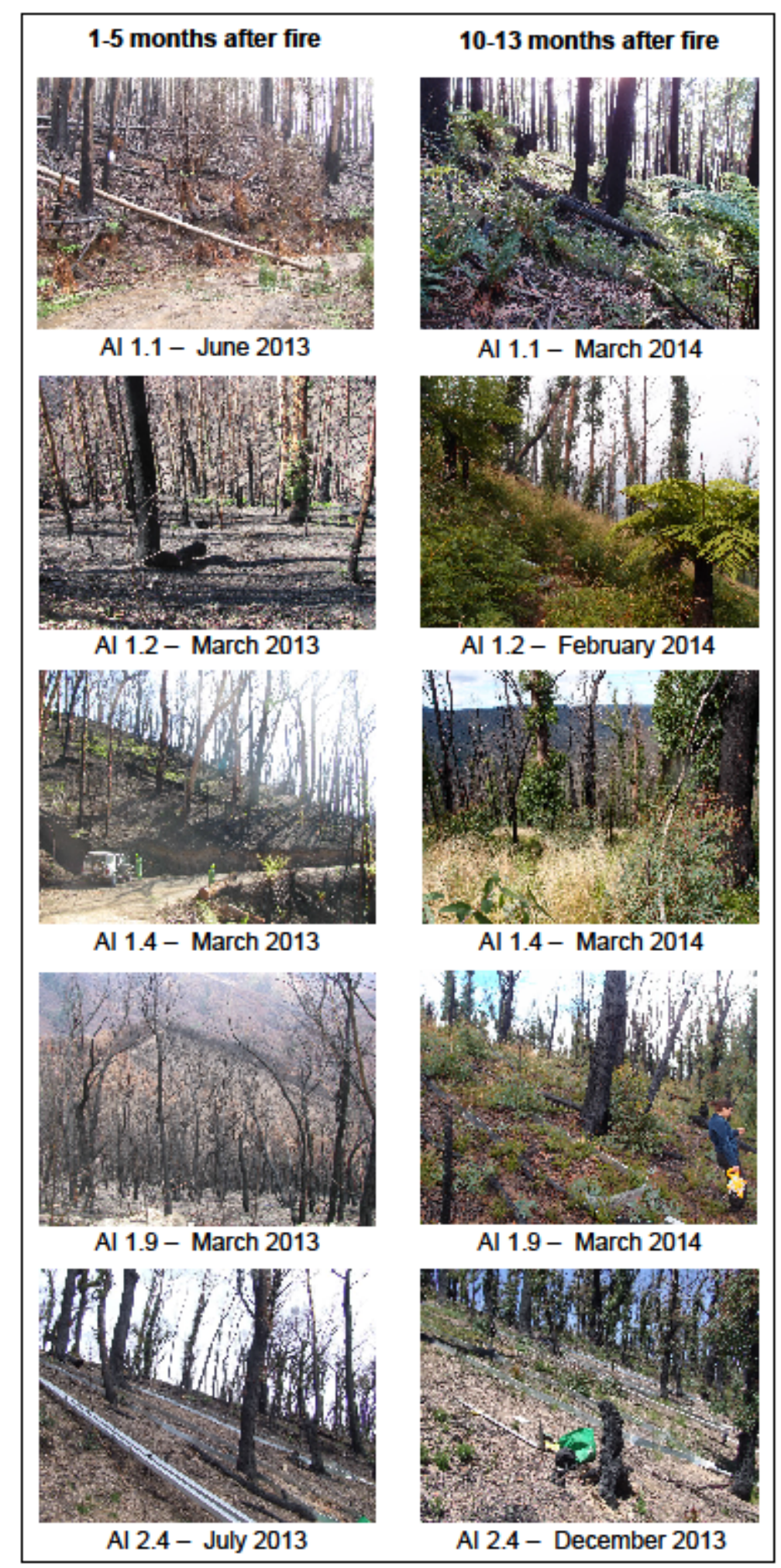

This article is protected by copyright. All rights reserved. 
Figure 3

This article is protected by copyright. All rights reserved. 


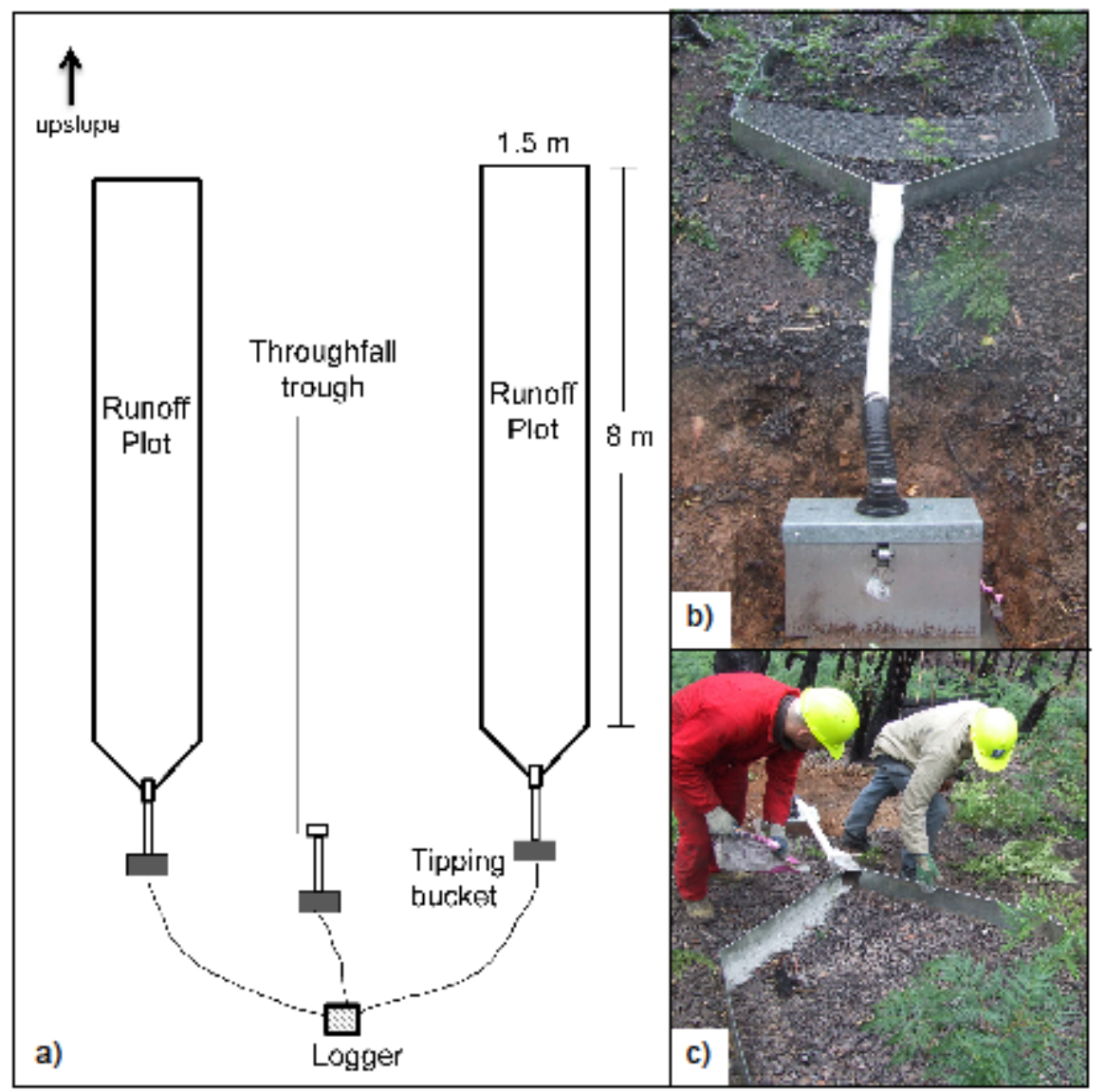

Figure 4

This article is protected by copyright. All rights reserved. 
a)

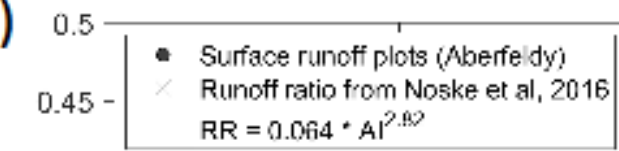

$0.4-$

$0.35-$

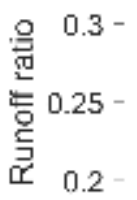

0.15

0.1

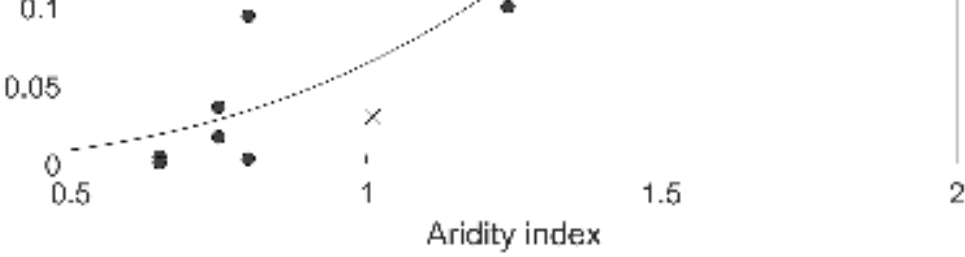

b) $17.5-$

$15-$

12.5

Peak runuff
$\left(\mathrm{mm} \mathrm{h}^{-1}\right) 7.5 \cdot$

$5-$

2.5 .

5.5

0

10

20

Peak rainfall intensity

$\left(\mathrm{mm} \mathrm{h}^{-1}\right)$

This article is protected by copyright. All rights reserved. 
figure 5

This article is protected by copyright. All rights reserved. 
a)

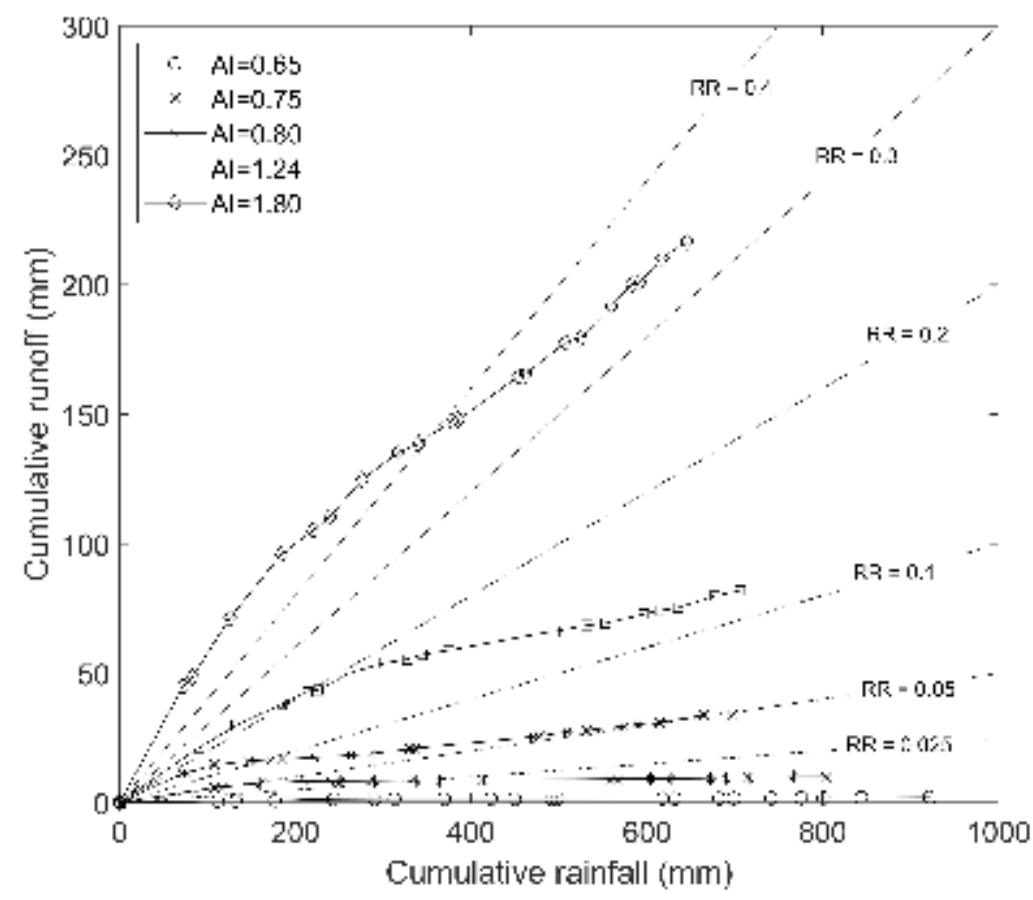

b)

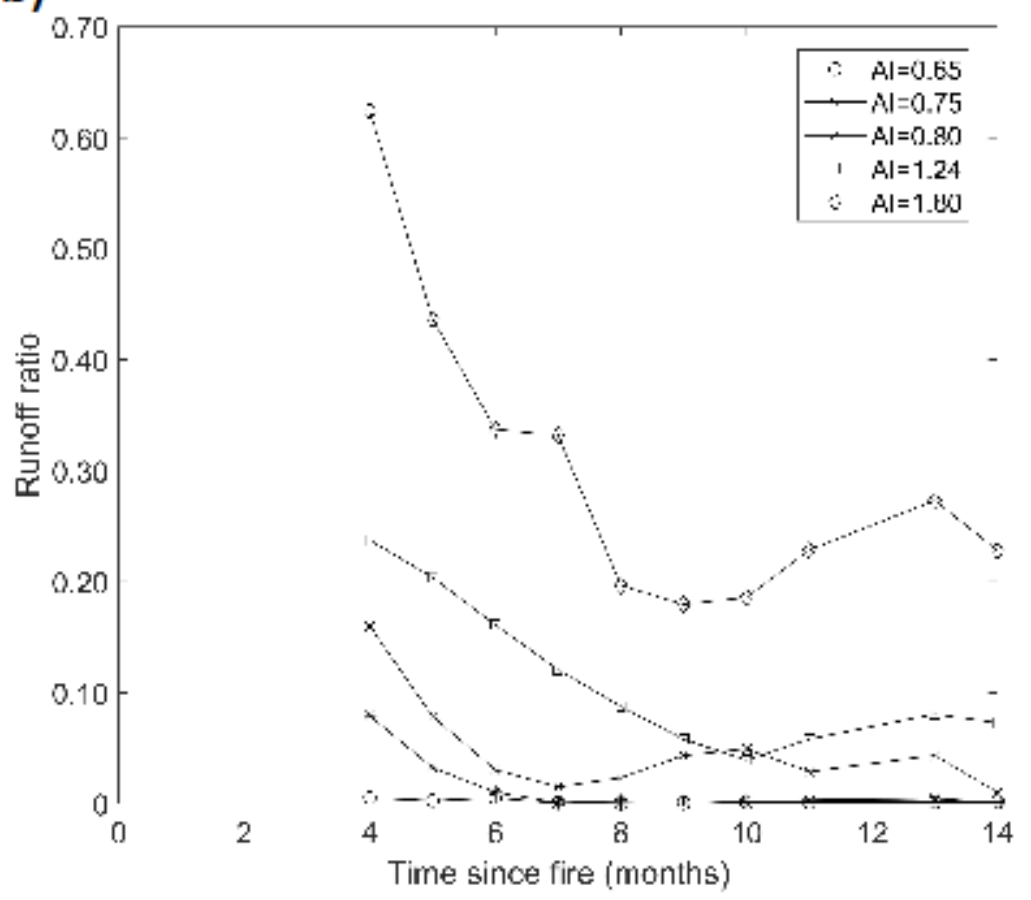

This article is protected by copyright. All rights reserved. 
Figure 6

This article is protected by copyright. All rights reserved. 


\section{University Library}

\section{- M M N E R VA A gateway to Melbourne's research publications}

Minerva Access is the Institutional Repository of The University of Melbourne

Author/s:

Van der Sant, RE;Nyman, P;Noske, PJ;Langhans, C;Lane, PNJ;Sheridan, GJ

Title:

Quantifying relations between surface runoff and aridity after wildfire

Date:

2018-08-01

Citation:

Van der Sant, R. E., Nyman, P., Noske, P. J., Langhans, C., Lane, P. N. J. \& Sheridan, G.

J. (2018). Quantifying relations between surface runoff and aridity after wildfire. EARTH

SURFACE PROCESSES AND LANDFORMS, 43 (10), pp.2033-2044. https://doi.org/10.1002/ esp.4370.

Persistent Link:

http://hdl.handle.net/11343/283917 